\title{
Managing Athletic Department Touch Points: A Case Study of One Institution Using Importance-Performance Analysis
}

\author{
Chris Chard \\ Brock University \\ Joanne MacLean \\ University of the Fraser Valley \\ Brent Faught \\ Brock University
}

\begin{abstract}
Athlete recruitment and delivery of the sport experience are critical components in determining the success of intercollegiate athletic teams and programs. Here, the athletic department brand and the associations of the brand achieved through "touch points" influence student-athletes' perceptions of the athletic department. The purpose of this study therefore was to understand the perceptions held by student-athletes about the brand of the athletic department. Importance-Performance Analysis (IPA) and brand touch point theory were used to accomplish the study's objective. Specifically, the authors analyzed surveys from 149 student-athletes based at one university in Ontario, Canada to consider athletic department "touch points." The results proved beneficial for highlighting areas of discrepancy between deemed importance and performance on key recruitment and delivery attributes including scholarship support, spectator support, special treatment, recognition, and quality of facilities.
\end{abstract}

Keywords: university athletics, brand, touch points, recruitment, retention, importance-performance analysis

One of the fundamental requirements of a successful university athletic department is the ability to attract the best student-athletes to represent the institution in varsity competitions (Dailing, 2002; Le Crom, Warren, Clark, Marolla, \& Gerber, 2009; Letawsky, Schneider, Pedersen, \& Palmer, 2003; Ryan, Groves, \& Schenider, 2007). While the National Collegiate Athletic Association (NCAA) garners much

Chard is with the Dept. of Sport Management, Brock University, St. Catharines, Ontario, Canada. MacLean is with the Faculty of Health Sciences, University of the Fraser Valley, Chilliwack, BC, Canada. Faught is with the Dept. of Community Health, Brock University, St. Catharines, Ontario, Canada. 
of the attention for university sport leagues in North America, other sporting bodies are also involved in this competition for student-athletes' services. For example, coaches within the National Association of Intercollegiate Athletics (NAIA) in the United States, and the Canadian Interuniversity Sport (CIS) and Canadian Collegiate Athletic Association (CCAA) in Canada, each seek to attract the highest level of athletic talent to play for their teams.

\section{Post-Secondary Sport in Canada and the United States}

Considering the Canadian-based postsecondary sporting organizations specifically, administrators of the CIS oversee the 52 member schools that are organized into four regional associations. Here, the central provinces of Ontario and Quebec have their own associations. The universities located in the provinces west of Ontario form a third association while the four provinces east of Quebec combine to form the fourth association. Within the CCAA, a similar geographic breakdown occurs, creating five regional associations with 100 member institutions. These associations or conferences can be found in the Pacific West, Alberta, Ontario, Quebec, and the Atlantic provinces. If one considers an Ontario-based student-athlete as an example, recruitment is highly competitive given that 19 universities and 29 colleges exist within the province offering relatively broad based sport programming in more than 25 sports (OCAA, 2011; OUA, 2012). In addition, competent student-athletes within this region would also likely field recruitment offers and therefore consider universities in other Canadian provinces, the NCAA and the NAIA within their decision analysis.

The breadth of postsecondary athletic offerings in the United States is significantly more substantial than in Canada. Administrators of the NCAA oversee approximately 1,100 member institutions dispersed across the nation in over 30 conferences (Brown, Rascher, Nagel, \& McEvoy, 2010). In addition, more than 300 member universities compete in the NAIA housed within one of the 23 conferences, again, situated in locations geographically spread across the country (NAIA, 2012).

\section{Competitive Market}

Given the competition for student-athlete services from the myriad athletic departments housed in the aforementioned organizations, it is understandable that athletic department coaches and administrators focus considerable resources (both fiscal and human) on identifying and developing relationships that connect and ultimately bond an athlete and the institution, its coach and team (Funk, 1991). For example, recruitment visits that include meeting key personnel and members of the team, tours of residences and athletic facilities, and tickets to a home sports event (to the maximum allowable without violating league rules) all are designed to bond an athlete with an institution. From the student's perspective, these bonds and associations are each considered when choosing which university to attend. Further, these (and other) associations influence student athletes' assessment of the athletic department's delivery of the sport experience after the school choice decision has been made. For example, special treatment for student-athletes, such 
as access to a varsity weight room or provision of team apparel, could influence the sport experience. Indeed, these perceptions are based on many factors of varying importance and include both broad criteria and whimsical emotions (Sevier, 2000).

We suggest that one component of having success in athlete recruitment and delivery involves understanding the perceptions held by student-athletes about the brand of the athletic department. Davis (2000) defines a brand as, "every touch point your organization has with its ultimate consumer, regardless of industry, regardless of company. These touch points represent the perceptions we build up in our minds about that brand" (p. 5). Thus, if a brand is the cumulative perception of associations and experiences with touch points, brand management is the process "that tries to take control over everything a brand does and says, and the way in which it is perceived" (Temporal 2002, p. xiii). Indeed, "there is growing support for viewing and managing the brand as an asset and thus having the brand drive every strategic and investment decision" (Davis \& Dunn 2002, p. 15), regardless of industry.

We contend therefore that those in charge of university athletic departments need to invest in research to identify areas in need of managerial attention within the athlete recruitment and delivery processes. As such, the objective of this research is to understand the perceptions held by student-athletes about the brand of the athletic department. To accomplish our objective we present an empirical investigation of the perceptions of 149 student-athletes at a midsized university based in Ontario, Canada using brand touch point theory and importance-performance analysis.

\section{Theoretical Framework}

We theoretically frame the study by presenting a brief background on brand management in university sport, specifically from the perspective of student-athletes as consumers. Next, we provide a detailed consideration of brand touch point theory. Finally, importance-performance theory is discussed as it relates to brand management.

\section{Brand Management in University Sport for Student-Athletes}

While scholars have investigated the brand equity of intercollegiate sport (Gladden, Milne, \& Sutton, 1998; Robinson \& Miller, 2003; Ross, Bang, \& Lee, 2007), specific attention on the influence of the athletic department's touch points and interactions with student-athletes has received little attention. According to Judson, James, and Aurand (2004), the benefits of a distinctive brand that is well understood by a coaching staff and incorporated into its daily activities are boundless. Indeed, university administrators have begun to view prospective students akin to consumers, considering their university choices similar to evaluating institutional brands (Abramson, 2000; Buckalew, 2002; Dawes \& Brown, 2004). In this regard, Klenosky, Templin, and Troutman (2001) acknowledge that this consumption decision is especially difficult for student-athletes given the multifaceted expectations they have of the university and athletic department. Here, points of contact between the student-athlete and athletic department can shape perceptions and influence desire to attend a specific university. Further, these points of contact can also shape perceptions on the delivery of the athletic experience. A better understanding of brand touch point theory is therefore warranted. 


\section{Brand Touch Point Theory}

As Davis (2005) argues, "It's increasingly understood that brand is about far more than just advertising and logos. It's about the relationship forged between an entity and its products and services - represented by the brand - and customers" ( $p$. 226). In the current context, the brand is about the relationship between studentathletes, both current and prospective, and the university athletic department. This relationship is fostered through all the points of contact the athletic department has with student-athletes. Managers need to use all available touch points a brand has with its consumers to create positive perceptions about the brand (Hollis, 2008). Identifying points of contact between organizations and customers, where brand building occurs therefore is the first step in improving brand management (George, 2003). And, since each organizational touch point leaves an impression (both good and bad) on customers, employees and stakeholders (Aaker, 1996), it is imperative for managers to keep track of where and how consumers interact with the brand. Davis and Dunn (2002) placed these brand-building interactions within one of three touch point experience categories: prepurchase, purchase, and postpurchase. In the context of the current research, such brand-building categorizations might usefully be delineated into two specific stages: recruitment and delivery. A third categorization will also be discussed addressing touch points that might equally influence both recruitment and delivery.

\section{Recruitment Stage}

Recruitment touch points include the myriad ways potential student-athletes interact with an athletic department brand before final decision-making. Conceptually, this stage can be perceived in two phases: awareness-building and brand selection. First, awareness-building involves the formation of the relationship between consumers and the brand (Davis, 2005). Here, recognition is a key factor for the brand experience (Aaker, 1996) as organizational touch points serve to influence whether the brand will be considered in consumers' final decision-set. For example, if a prospective student-athlete had attended an ABC Tigers' university sports camp when she was young, a relationship will have been previously formed. Here, an awareness and comfort level with the campus, facilities, food service, and athletic teams' brand will already be established. Other associations to build awareness and foster rapport might include a quality website and community relations programs.

The second phase of recruitment touch points are those that influence an athlete (the consumer) to move from consideration of a prospective brand to brand selection (Davis \& Longoria, 2003). At this stage student-athletes will already have formed an initial impression of the athletic department and will be further exploring the utility of the brand for their satisfaction. While no concrete decisions have been made at this point, the goal is to convert a potential customer into an actual customer (Venkat, 2005). In the context of the current study, this stage is about converting a recruit into a student-athlete who will represent the university in varsity competition. For example, the reputation of the coaching staff and the history of the university's teams may be celebrated at this stage and shape perceptions of the athletic department's brand. 


\section{Delivery Stage}

Adhering to the brand promise, meeting or exceeding customer expectations, and increasing brand loyalty and advocacy are the three goals of delivery-stage brand touch points (George, 2003). The focus here is on building and fostering relationships with student-athletes through successful delivery against expectations (Barrera, 2005). As with any service, failure to deliver what the consumer expects will result in dissatisfaction. For example, a highly recruited student-athlete may choose a specific university because the team has a history of outstanding support and on-field success. Should the team falter, however, and the fan base erode, the expectations of the student-athlete may be left unfulfilled.

Clearly, the goal during the delivery stage is to establish customer (athlete) satisfaction and encourage ongoing, positive promotion (Venkat, 2005). Indeed, efforts to deliver satisfaction to athletes and to develop these individuals into loyal alumni have been noted before (Wohlgemuth, Whalen, Sullivan, Nading, Shelley, \& Wang, 2007). Examples of delivery stage touch points include special treatment and fan support. Here, delivery (or not) against expectations may shape brand perceptions, athlete satisfaction, and advocacy levels of the student-athlete in the future.

\section{Recruitment and Delivery Stage}

Some touch points might equally be considered to influence both recruitment and delivery of the athletic experience. For example, the influence of quality facilities during recruitment has been noted before (Klenosky et al., 2001). Similarly, these same facilities might be influential in delivering a quality experience during a student-athletes' tenure at an academic institution.

In sum, a strong brand is able to form a personal and emotional relationship with consumers; in time this creates brand loyalty (Parent \& Seguin, 2008). Here, relationships are fostered over a continuum of brand experiences that include the recruitment and delivery stages of engagement. In the current research therefore the objective is to understand the perceptions held by student-athletes about the brand of an athletic department specifically considering the brand touch points encountered in the recruitment and delivery stages. To do so, importance-performance analysis is used and will be considered next.

\section{Importance-Performance Analysis}

Importance-Performance Analysis (IPA) is a research technique designed to analyze consumer attitudes toward relevant product or service attributes (Joppe, Martin \& Whalen, 2001). The technique allows for simultaneous consumer feedback on the perceived importance of these attributes as well as the consumers' evaluation of the service provider. For example, a survey question might ask: "How important is cleanliness to your satisfaction of XYZ Organization?" Later in the survey, a question would read: "How is XYZ Organization performing on cleanliness?" Here, management could then determine how they are performing on cleanliness relative to consumers' reasoned importance on this particular attribute.

While IPA was originally developed by Martilla and James (1977) to guide management decisions in the field of marketing, given the utility of the tool to inform strategic initiatives there has been wide acceptance of IPA. Indeed, 
Importance-Performance theory has been applied to different areas of management including: tourism (Evans \& Chon, 1989; Joppe et al., 2001; Lee \& Lee, 2009), technology (Skok, Kophamel, \& Richardson, 2001), public policy (Lai \& To, 2010; Miranda, Chamorro, Murillo, \& Vega, 2010), health care (Hawes \& Rao, 1985), education (Ford, Joseph, \& Joseph, 1999), and leisure (Rial, Rial, Varela, \& Real, 2008). However, Tarrant and Smith (2002) note the lack of significant IPA application in sport management even though the tool has been identified as having "great potential" for sport services (Rial et al., 2008, p. 182).

For the current investigation, IPA provides an efficient and effective means of capturing student-athletes' perceptions of the athletic department's performance relative to deemed importance on particular touch points. Whereas a traditional "performance" or "satisfaction" survey provides feedback on one aspect of an attribute, IPA also captures a second dimension: the importance of the attribute. Thus, knowing that your organization is performing at a " 7 out of 10 " on cleanliness is interesting; however, knowing that your customers deem this facet of your offering to be a " 9 out of 10 " on importance provides deeper understanding.

\section{Conducting and Reporting IPA Research}

IPA begins with the origination of a list of attributes on which an assessment is to be performed. This list is central to the examination and is commonly obtained through literature review and dialogue with individuals knowledgeable about the context (Skok, et al., 2001). The next stage of the IPA involves the development of a survey instrument using Likert scales, which is then sent to respondents. Here, "the importance and performance measures must actually be separated from each other to eliminate the natural bias which would occur if they were measured together" (Ford et al., 1999, p.173). Upon receipt of the completed surveys, the importance and performance of the listed attributes can be plotted against each other in a two dimensional grid, with the importance scores are plotted on the vertical axis while perceived performance is plotted on the horizontal axis (Skok et al., 2001) (see Figure 1.).

One of the utilities of IPA is the clear visual identification of the stronger and weaker aspects of a given service (Slack, 1994). Once all of the attribute means are determined, the mean values from all of the importance and performance scores ("grand means") are used to create the "crosshairs" of the IPA grid. Further enhancement to IPA maps has recently been introduced by incorporating discrepancy into the model (Abalo, Varela, \& Manzano, 2007). Discrepancy is determined by adding a diagonal line to the matrix, and items above the line where performance scores are less than importance are said to have negative discrepancy. This negative discrepancy displays a level of customer dissatisfaction and/or managerial opportunity. Items below the discrepancy line indicate where performance scores are greater than importance scores indicating satisfaction. When an item sits on the diagonal line there is no discrepancy at all-performance is equal to the importance placed on the item. All things being equal, the further an item sits above the discrepancy line the more managerial attention the item should receive.

Given the utility of IPA, it is suitable to assess perceptions of studentathletes. The objective of this research was to understand the perceptions held by student-athletes about the brand of an athletic department. The purpose of 


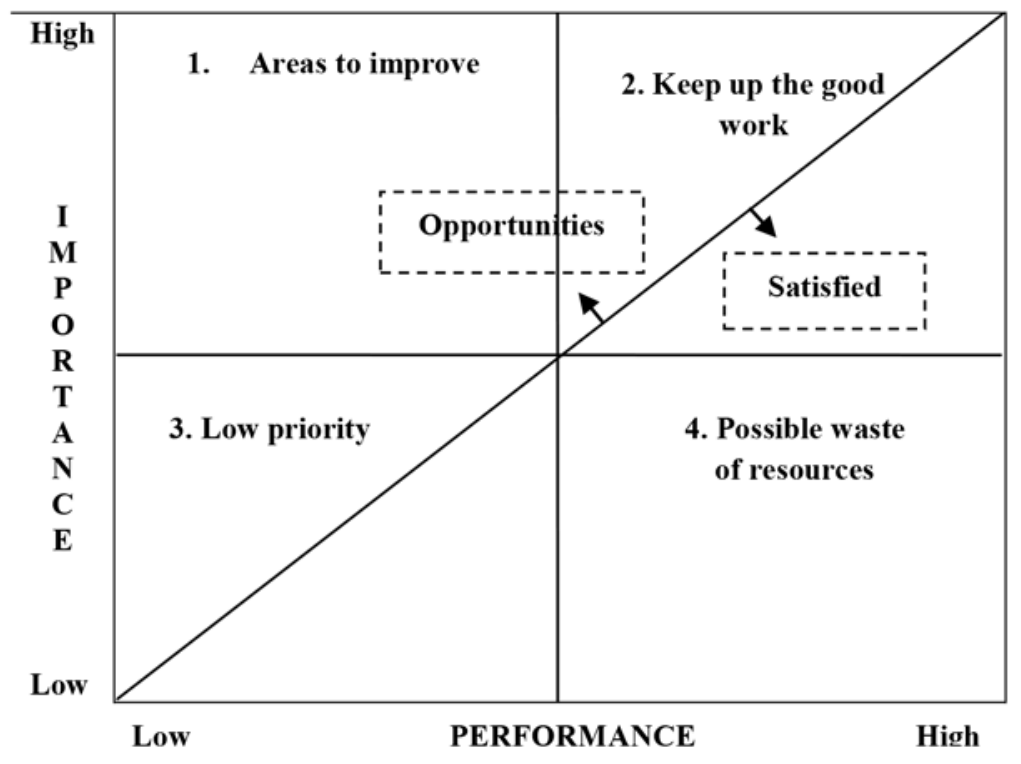

Figure 1 - Representation of IPA grid showing crosshairs and discrepancy (Rial, Rial, Varela, and Real, 2008)

enhancing understanding in this area was to assist athletic department personnel to effectively recruit and deliver a quality sport experience to student-athletes. The brand touch point model used for the investigation is theoretically derived from the literature and for the purpose of this study was investigated in the context of a university athletic program in Ontario, Canada. Exploring a school in Ontario, Canada was deemed to be suitable for the current investigation given the highly competitive nature of athlete recruitment in this jurisdiction (OUA, 2001). For example, influences such as (a) the proximity to the United States and thus the NCAA and NAIA, (b) the number of colleges and universities within Ontario, and (c) the league level legislation that reduces athletic scholarship dollar amounts that an athlete is allowed to receive per year in the OUA compared with the other CIS conferences (CIS, 2011), each contribute to the significant competition for athletic talent.

\section{Method}

\section{Participants}

Students-athletes $(N=149)$ participating in athletics at a university in Ontario, Canada took part in the study. The sample consisted of 73 men and 76 women. The men were representative of 13 different varsity sports, while the women took part in 11 different sports. 


\section{Measures}

According to Hawes and Rao (1985), IPA must begin with an identification of salient attributes that are relevant to the situation being examined. To this end, the study instrument was developed through a two-stage process. First, a preliminary list of 35 measurement items was generated via an in-depth literature review pertaining to potential recruitment and delivery touch points (Cooper, 1996; Chelladurai \& Riemer, 1997; Davis \& Dunn, 2002; Dawes \& Brown, 2004; Gladden, Milne, \& Sutton, 1998; Goss, Jubenville, \& Orejan, 2006; Johnson, Jubenville, \& Goss, 2009; Judson, James, \& Aurand, 2004; Klenosky et al., 2001; Miller \& Kerr, 2002). The items included potential touch points involving awareness, athlete recruitment, and athlete satisfaction/delivery.

The second step involved dialogue with individuals knowledgeable about the context of the investigation (Skok, et al., 2001). Here, two former university Athletic Directors and coaches from Ontario were invited to (a) review the list, (b) add to it where warranted, and (c) select the items that they felt, given their experience and nuances of the Ontario marketplace, reflected important issues in building and managing the athletic department brand for athlete recruitment and delivery. Ultimately, the two experts selected 18 items; however, after further review, three of the touch points were ultimately removed from the study (desirable academic programs, academic reputation of the university, and range of sports offered). The first two were omitted as they represent items beyond the managerial influence of the athletic department staff. The last attribute was eliminated because the overwhelming majority of studentathletes are focused on just one sport, and thus, the range of offerings was deemed to be of little relevance. The final touch point items are presented in Table 1.

The stem to discern the deemed "importance" factors read: To satisfy prospective and current student-athletes and make [university's] Athletic Department the best it can be, how important are the following items to achieve this goal? Participants responded on a 10-point Likert scale from 1 (not important at all) to 10 (critical importance). Here, the researchers chose to employ a 10-point scale to encourage a wider range of options and to enhance broader distributions as recommended by Joppe et al. (2001). Similarly, to discern the perceived level of performance on the same factors, the stem read: Specifically, considering [university's] Athletic Department, how well is the department performing in delivering the following items to prospective and current student-athletes? Participants again responded on a 10-point Likert scale from 1 (well behind industry leaders) to 10 (leading the industry).

\section{Procedures}

Data collection for this investigation was completed in two phases. First, a pilot test was conducted with the on-line questionnaire in which 5 individuals outside the frame of the study but familiar with intercollegiate sport completed the survey to provide feedback on the clarity of questions and performance of the on-line portal. Their feedback resulted in minor adjustments to the wording of a few items. Second, the researchers sought feedback from the student-athletes of the university. The Athletic Director (AD) at the university under investigation provided e-mail addresses for the researchers to contact potential respondents. In addition, the $\mathrm{AD}$ sent an introductory e-mail before the launch of the survey to introduce the 


\section{Table 1 Importance-Performance Touch Point Items}

\begin{tabular}{ll}
\hline Attribute & Recruitment Touch Points \\
\hline A & Quality of the athletics website \\
B & Sport specific summer camps \\
C & Coaches watching high school games \\
D & Coaches' involvement with prov/nat teams \\
E & Community relationship programs \\
F & Reputation of sports teams for success \\
G & Reputation of coaches \\
\hline & Delivery Touch Points \\
\hline H & Delivering athletic success to athletes \\
I & Fostering relationships within teams \\
J & Recognition given to varsity athletes \\
K & Environment for academic success \\
L & Special treatment (apparel. . .) \\
\hline & Recruitment \& Delivery Touch Points \\
\hline M & Scholarship support \\
N & Quality of athletic facilities \\
O & Spectator support at varsity contests \\
\hline
\end{tabular}

research, thereby providing an endorser role (Dillman, 2000). Surveys were sent to student-athletes through an e-mail invitation which contained a link to an on-line questionnaire via a secure web-portal.

In total, 561 e-mails were sent to student-athletes. Reminder e-mails were automatically generated and sent to nonrespondents after 5 days; a second reminder was issued 10 days later (Dillman, 2000). This process yielded 149 useable surveys, with a $27 \%$ participation rate.

\section{Results}

Each attribute mean was plotted on a two-dimensional grid indicating importance levels on the x-axis and performance levels on the y-axis. Subsequently, we calculated "grand means" for both importance and performance attributes to establish the "crosshairs" of the diagram. Finally, the diagonal discrepancy line (Abalo et al., 2007) was added to visually show the incongruity between importance and performance scores.

\section{Touch Point Importance Rankings}

The overall, men's, and women's means (out of 10) for importance and performance with resultant discrepancy for each of the individual brand attribute IPA scores is 
displayed in Table 2. From the table it is clear that the student-athletes perceived the importance of all of the 15 brand touch points to exceed the deemed delivery (determined by the negative discrepancy scores). Opportunities for improvements and managerial intervention therefore exist.

\section{Importance-Performance Analysis}

The IPA map (see Figure 2.) shows the overall results of the importance of each attribute relative to deemed delivery.

The five $(33.33 \%)$ touch point attributes clustered in the areas to improve quadrant were (in order of priority based on discrepancy) "scholarship support," "spectator support at varsity contests," "special treatment," "recognition given to varsity athletes," and "quality of athletic facilities." Each attribute was rated below

Table 2 Mean Scores for Importance and Performance With Resultant Discrepancy

\begin{tabular}{|c|c|c|c|c|}
\hline \multirow[b]{2}{*}{ Item } & \multirow[b]{2}{*}{ Description } & \multicolumn{3}{|c|}{ Overall } \\
\hline & & Imp. & Perf. & Disc. \\
\hline & Recruiting Stage Touch Points & & & \\
\hline A & Quality of the athletics website & 7.12 & 6.32 & -0.80 \\
\hline B & Sport specific summer camps & 6.63 & 6.30 & -0.32 \\
\hline $\mathrm{C}$ & Coaches watching high school games & 6.52 & 5.47 & -1.05 \\
\hline $\mathrm{D}$ & Coaches' involvement with prov/nat teams & 7.30 & 6.29 & -1.01 \\
\hline $\mathrm{E}$ & Community relationship programs & 7.35 & 6.57 & -0.78 \\
\hline $\mathrm{F}$ & Reputation of sports teams for success & 8.28 & 6.64 & -1.65 \\
\hline \multirow[t]{3}{*}{ G } & Reputation of coaches & 7.91 & 6.48 & -1.43 \\
\hline & Mean recruiting-stage touch point scores & 7.30 & 6.30 & -1.01 \\
\hline & Delivery Stage Touch Points & & & \\
\hline $\mathrm{H}$ & Delivering athletic success to athletes & 8.20 & 6.59 & -1.60 \\
\hline I & Fostering relationships within teams & 7.78 & 6.12 & -1.65 \\
\hline $\mathrm{J}$ & Recognition given to varsity athletes & 8.10 & 5.10 & -3.00 \\
\hline $\mathrm{K}$ & Environment for academic success & 7.69 & 6.34 & -1.36 \\
\hline \multirow[t]{3}{*}{$\mathrm{L}$} & Special treatment (apparel. . .) & 8.30 & 5.17 & -3.14 \\
\hline & Mean delivery-stage touch point scores & 8.01 & 5.86 & -2.15 \\
\hline & Recruiting \& Delivery Stage Touch Points & & & \\
\hline M & Scholarship support & 8.41 & 4.58 & -3.83 \\
\hline $\mathrm{N}$ & Quality of athletic facilities & 8.60 & 5.73 & -2.87 \\
\hline \multirow[t]{3}{*}{$\mathrm{O}$} & Spectator support at varsity contests & 8.06 & 4.40 & -3.65 \\
\hline & Mean recruiting \& delivery-stage touch point scores & 8.35 & 4.90 & -3.45 \\
\hline & Grand Means & 7.75 & 5.87 & \\
\hline
\end{tabular}




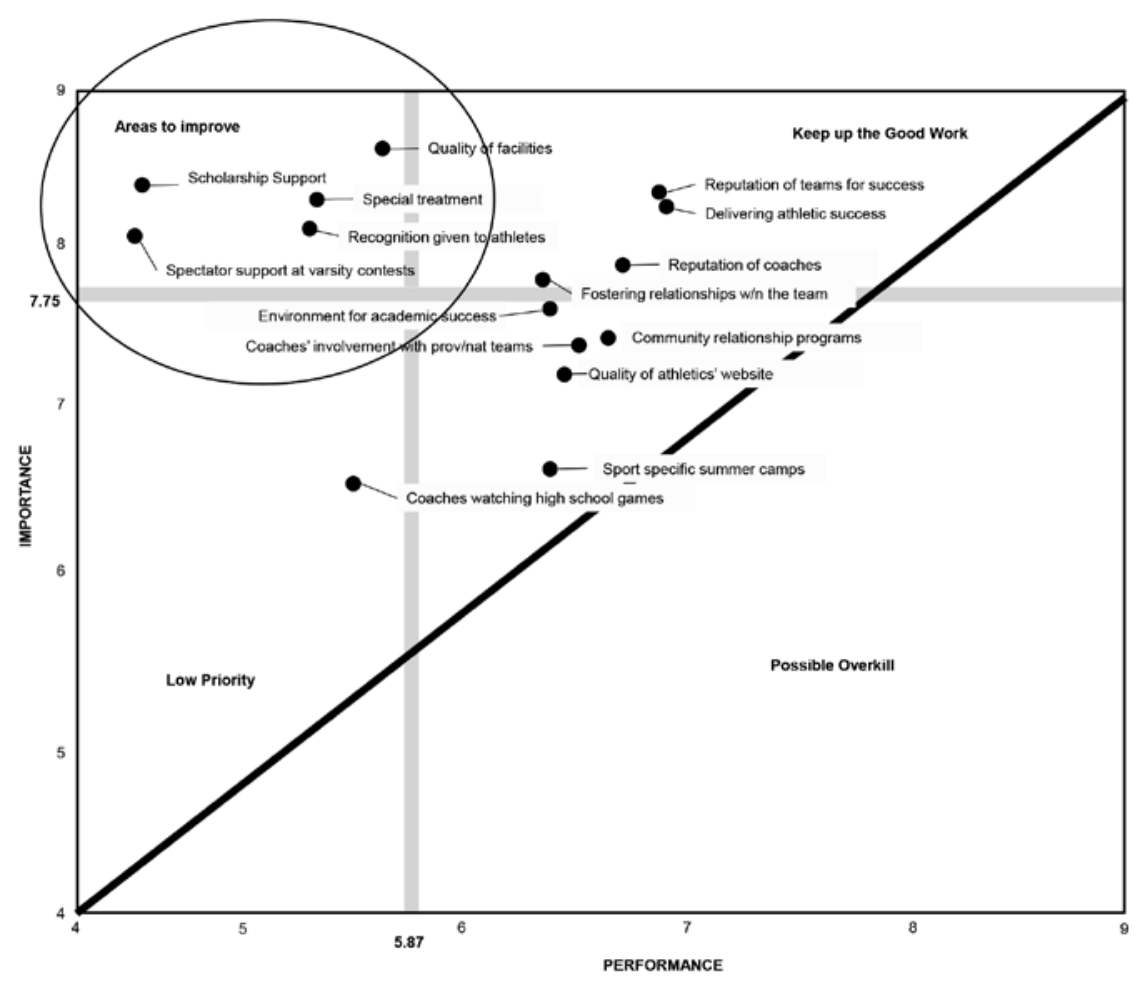

Figure 2 - Overall student-athletes' perceptions of the athletic department

average on performance and above average on importance; this implies that more resources should be directed at these high priority brand elements.

Another four $(26.66 \%)$ touch point attributes were located in the upper-right quadrant entitled "keep up the good work." Here, attributes were above average in both importance and performance. Each attribute still had a negative discrepancy score, however, meaning that opportunities for managerial attention to enhance the offering still exist. Again, listed according to discrepancy, the touch points in this quadrant include "reputation of sports teams for success," "fostering relationships within the team," "delivering athletic success to athletes," and "reputation of the coaches."

Only one $(6.66 \%)$ touch point was deemed to be of low priority, "coaches watching high school games," as student-athletes deemed it below average for both importance and performance scores. Resources directed at this activity might wisely be questioned.

Finally, we identified five touch point attributes (33.33\%) within the bottomright quadrant (possible overkill). The attributes, listed according to discrepancy, include "environment to promote academic success," "coaches' involvement with provincial/national teams," "quality of athletics website," "community relations 
programs," and "sport specific summer camps." Here, each attribute was rated above average on performance and below average on importance.

\section{Discussion}

While studies on student-athletes have been conducted (Cooper, 1996; Johnson et al., 2009; Goss et al., 2006; Klenosky et al., 2001), these investigations typically focus on athlete recruitment. Indeed, there is a gap in the research that also addresses the subsequent delivery of the athlete's experience once school-choice decisions have been made. As a result, to understand the perceptions held by student-athletes on recruitment and delivery processes at one postsecondary institution in Ontario, Canada, touch point theory and importance-performance analysis proved very useful. Indeed, identifying pertinent touch points provides flexibility to Athletic Directors and/or coaches to assess the points-of-contact between the athletic department and student-athletes. The subsequent use of TPA provides a tool to better understand and prioritize initiatives to enhance student-athlete satisfaction at the recruitment and delivery stages.

The results of the current investigation reveal that specific organizational touch points can be usefully placed into one of four operational quadrants (areas to improve, keep up the good work, possible overkill, and low priority). In addition, the touch points can handily be viewed as "opportunities" or "satisfied" depending on where they sit in relation to the discrepancy line. Diminishing returns would suggest that prioritizing initiatives should be a managerial goal; therefore, a focus on the brand touch points contained within the quadrant entitled "areas to improve" (in the top-left quadrant) and those that are farthest from the discrepancy line (Abalo, et al., 2007), should provide the focal point of managerial attention and will be discussed next.

\section{Managerial Attention}

We identified five touch point attributes ("scholarship support," "spectator support at varsity contests," "special treatment," "recognition given to varsity athletes," and "quality of athletic facilities") most needing managerial attention (given the largest discrepancy scores). Considering scholarship support, the lack of sufficient funds to compete with schools in the United States has led to a phenomenon called "brawn drain" (Bale, 1991; Miller \& Kerr, 2002), where student-athletes leave Canada to achieve their schooling and athletic development south of the border. A growing concern in Ontario however is the "brawn drain" that is now occurring within Canada. Given that OUA institutions cannot offer as much scholarship money to student-athletes (compared with the western and eastern provinces) this financial hindrance is clearly an issue. Scholarship support was thus unsurprisingly the touch point with the greatest overall discrepancy between importance and performance.

With regards to spectator support at varsity contests, the sport management literature is replete with information on marketing to fans (Funk \& James, 2006; Gladden \& Funk, 2001; Mahony, Madrigal, \& Howard, 2000; Ross, 2006) to create positive experiences for the paying customer. The importance of such initiatives, however, might also be felt when student-athletes consider selecting a university to attend and the willingness of these individuals to advocate for the institution to 
prospective student-athletes in the future. Indeed, Klenosky et al. (2001) identified the opportunity to play in front of friends and family as an important consideration of school-choice for football recruits. Overall, student-athletes viewed the current support at varsity contests to be unsatisfactory. Continued research and work to market to fans would thus seem to be an effective use of resources.

The touch points addressing special treatment and recognition given to varsity athletes both provide interesting points for discussion from a managerial perspective. Clearly, rules are established to limit (ideally eradicate) behaviors that contravene league policies with respect to interactions with student-athletes. For example, buying incoming student-athletes a new car would certainly be classified as "special treatment" and may sway their decision to attend a specific institution. Such lavish expenditures, however, are in clear violation of all postsecondary leagues' (NCAA, NAIA, CIS, CCAA) regulations. In the current investigation, special treatment was referred to in the context of comfortable travel to games, apparel for training, access to gym facilities, and equipment for competition. In Canada, some programs supply very little to their athletes (e.g., old equipment and cost-conscious travel), while others provide a more robust offering (e.g., training apparel, new equipment, and flights to certain road games). The results indicate that athletes place significant value on receiving special treatment; energies to deliver on this touch point are thus warranted. For example, simple provision of free memberships to the campus gym would likely create some positive equity.

In a similar vein, recognition given to varsity athletes was an attribute in need of attention. While human resource literature has addressed numerous forms of employee recognition including simple praise to fiscal rewards (Long \& Shields, 2010), the various ways to acknowledge student-athletes remains somewhat unclear. The current findings indicate that student-athletes at the institution under investigation certainly desire more recognition for their efforts. Understanding the ways in which athletes would like to be recognized would appear to be of value.

The quality of the athletic facilities has been noted as an influence on spectator attendance and enjoyment of athletic contests (Hill \& Green, 2000; Wakefield \& Sloan, 1995; Wakefield, Blodgett, \& Sloan, 1996); perhaps, the same influence on athlete satisfaction and delivery of the athletic experience might be present. Certainly, researchers focusing on recruitment have addressed the issue of facility quality; for example, Klenosky et al. (2001) noted the significant impact of facilities on football players' school-choice decision-making. More recently, Ryerson University's new athletic facility (located in the old Maple Leaf Gardens in downtown Toronto) is being positioned as the centerpiece of a new era in the school's athletic competition (MacLeod, 2012). One might argue that on-going participation in high/low quality venues could shape the perceptions of student-athletes and influence their advocacy of the athletic department in the long run. Therefore, capital campaigns to construct new, or refurbish existing, facilities might be beneficial for enhancing this touch point.

\section{Limitations, Future Directions, and Conclusions}

Despite the contributions of this work, we are aware of potential limitations. First, IPA is produced from the perceptions of individual respondents on the delivery against identified brand touch points. Taken in aggregate, the information surely 
gives managerial insights into the opinions and sentiment of those consumers and employees (or other constituents) who participate in an IPA; however, "perceptions are not always reality" and thus care is needed when implementing change. Another limitation relates to the student-athletes. Given that these individuals are currently students at the university under investigation, their delivery experience is not yet complete. Therefore, it is possible that their opinions could change with respect to the delivery stage touch points (i.e., a National Championship could alter perceptions of delivering athletic success). Finally, it should be clear that the results of the current investigation are not intended to be generalized to every athletic department in North America.

We also see several avenues for future research. This study highlights incongruity in the recruiting and delivery processes of a Canadian university athletic department using IPA. Future IPA studies should consider other athletic departments within Canada and the United States. Comparisons based on geography, country of origin, and competitive division could prove instructive. Further, establishing benchmarks for importance and performance scores at every university would be of value. Here, conducting IPA at regular intervals could assist athletic department personnel to assess changes in perceptions on a longitudinal basis. Demonstrating a focus on the wants and needs of student-athletes and showing, ideally, how the university's athletic department staff is able to deliver against expectations could assist in student-athlete recruiting. This iterative process could provide a point of differentiation for successful athletic departments.

In conclusion, our primary objective of this research was to understand the perceptions held by student-athletes about the brand of an athletic department. The purpose of enhancing understanding in this area was to assist athletic department personnel to effectively recruit student-athletes and deliver a quality sport experience. It became clear through IPA that the student-athletes in the current investigation perceived a significant level of incongruity between the importance of five specific touch points and the actual performance of the athletic department on these same items. Specifically, "scholarship support," "spectator support at varsity contests," "special treatment," "recognition given to varsity athletes," and "quality of athletic facilities" all represent touch points in need of managerial attention. Steps by the Athletic Director to address these incongruities would be wise.

\section{References}

Aaker, D.A. (1996). Building strong brands. New York: The Free Press.

Abalo, J., Varela, J., \& Manzano, V. (2007). Importance values for importance-performance analysis: a formula for spreading out values derived from performance rankings. Journal of Business Research, 60, 115-121. doi:10.1016/j.jbusres.2006.10.009

Abramson, P. (2000). Construction report. College Planning \& Management, 3, 20-27.

Bale, J. (1991) The brawn drain: Foreign student-athletes in American universities. Champaign-Urbana, IL: University of Illinois Press.

Barrera, R. (2005). Over promise and over deliver: Using touch point branding to design and deliver extraordinary customer experiences. Toronto, Ontario: Penguin Group.

Brown, M.T., Rascher, D.A., Nagel, M.S., \& McEvoy, C.D. (2010). Financial Management in the Sport Industry. Scottsdale, Arizona: Holcomb Hathaway.

Buckalew, L.G. (2002). Trends in Higher Education: Teaching and learning best practices and strategies. Boca Raton, FL: Siemens Enterprise Networks, LLC. 
Chelladurai, P., \& Riemer, H.A. (1997). A classification of facets of athlete satisfaction. Journal of Sport Management, 11(2), 133-159.

CIS. (2011). Canadian Interuniversity Sport: Eligibility rules. Retrieved August 14, 2011 from http://english.cis-sic.ca/information/members_info/bylaws_policies_procedures.

Cooper, K. (1996). What the basketball prospect wants to know about you! Coach and Athletics Director, 65(7), 24-26.

Dailing, K. (2002). Coaches breathe life into college sports with recruiting. Retrieved from http://www.highbeam.com/doc/1P1-53895257.html.

Davis, S.M. (2000). Brand asset management. San Francisco, CA: Jossey-Bass.

Davis, S.M. (2005). Building a brand-driven organization. In A.M. Tybout \& T. Calkins (Eds.), Kellogg on Branding (226-244). Hoboken, NJ: John Wiley \& Sons.

Davis, S.M., \& Dunn, M. (2002). Building the brand-driven business: Operationalizing your brand to drive profitable growth. San Francisco, CA: Jossey-Bass.

Davis, S., \& Longoria, T. (2003). Harmonizing your touch points. Brand Packaging. January/February, 17-23.

Dawes, P.L., \& Brown, J. (2004). The composition of consideration and choice sets in undergraduate university choice: An exploratory study. Journal of Marketing for Higher Education, 14(2), 37-59. doi:10.1300/J050v14n02_03

Dillman, D. (2000). Constructing the questionnaire. Mail and internet surveys. New York: John Wiley \& Sons.

Evans, M.R., \& Chon, K-S. (1989). Formulating and evaluating tourism policy using importance-performance analysis. Journal of Hospitality and Tourism Research Journal, 13(3), 203-213. doi:10.1177/109634808901300320

Ford, J.B., Joseph, M., \& Joseph, B. (1999). Importance-performance analysis as a strategic tool for service marketers: the case of service quality perceptions of business students in New Zealand and the USA. Journal of Services Marketing, 13(2), 171-186. doi:10.1108/08876049910266068

Funk, D. (1991). Major Violation: The unbalanced priorities in athletics and academics. Champaign, IL: Leisure Press.

Funk, D., \& James, J. (2006). Consumer loyalty: The meaning of attachment in the development of sport team allegiance. Journal of Sport Management, 20, 189-217.

George, R. (2003, September 16). Tapping into brand touch points. Retrieved from http:// www.marketingprofs.com/articles/2003/919/tapping-into-brand-touchpoints

Gladden, J., Milne, G., \& Sutton, W. (1998). A conceptual framework for evaluating brand equity in Division I college athletics. Journal of Sport Management, 12(1), 1-19.

Gladden, J., \& Funk, D. (2001). Understanding brand loyalty in professional sport: Examining the link between brand associations and brand loyalty. International Journal of Sports Marketing \& Sponsorship, 3, 67-94.

Goss, B.D., Jubenville, C.B., \& Orejan, J. (2006). An examination of influences and factors on the institutional selection processes of freshman student-athletes at small colleges and universities. Journal of Marketing for Higher Education, 16(2), 105-134. doi:10.1300/J050v16n02_05

Hawes, J.M., \& Rao, C.P. (1985). Using importance-performance analysis to develop health care marketing strategies. Journal of Health Care Marketing, 5(4), 19-25. PubMed

Hill, B., \& Green, C.B. (2000). Repeat attendance as a function of involvement, loyalty, and the sportscape across three football contexts. Sport Management Review, 3, 145-162. doi:10.1016/S1441-3523(00)70083-0

Hollis, N. (2008). The Global Brand: How to create and develop lasting brand value in the world market. New York: Millward Brown.

Joppe, M., Martin, D.W., \& Waalen, J. (2001). Toronto's image as a destination: a comparative importance-satisfaction analysis by origin of visitor. Journal of Travel Research, 39(February), 252-260. doi:10.1177/004728750103900302

Johnson, G.R., Jubenville, C., \& Goss, B. (2009). Using institutional selection factors to develop recruiting profiles: Marketing small, private colleges and universities to 
prospective student-athletes. Journal of Marketing for Higher Education, 19, 1-25. doi:10.1080/08841240902904513

Judson, K.M., James, J.D., \& Aurand, T.W. (2004). Marketing the university to studentathletes: understanding university selection criteria. Journal of Marketing for Higher Education, 14(1), 23-40. doi:10.1300/J050v14n01_02

Klenosky, D.B., Templin, T.J., \& Troutman, J.A. (2001). Recruiting student athletes: A means-end investigation of school-choice decision making. Journal of Sport Management, 15(2), 95-106.

Lai, L.S.L., \& To, W.M. (2010). Importance-performance analysis for public management decision making: An empirical study of China's Macao special administrative region. Management Decision, 48(2), 277-295. doi:10.1108/00251741011022626

Le Crom, C.L., Warren, B.J., Clark, H.T., Marolla, J., \& Gerber, P. (2009). Factors contributing to student-athlete retention. Journal of Issues in Intercollegiate Athletics, 14-24.

Lee, G., \& Lee, C-K. (2009). Cross-cultural comparison of the image of Guam perceived by Korean and Japanese leisure travelers: Importance-performance analysis. Tourism Management, 30, 922-931. doi:10.1016/j.tourman.2008.11.013

Letawsky, N.R., Schneider, R.G., Pedersen, P.M., \& Palmer, C.J. (2003). Factors influencing the college selection process of student-athletes: are their factors similar to non-athletes? College Student Journal, 37(4), 604-610.

Long, R.J., \& Shields, J.L. (2010). From pay to praise? non-cash employee recognition in Canadian and Australian firms. International Journal of Human Resource Management, 21(8), 1145. doi:10.1080/09585192.2010.483840

MacLeod, R. (2012, September 11). Ryerson has high hopes for sports. The Globe and Mail, S4.

Mahony, D., Madrigal, R., \& Howard, D. (2000). Using the psychological commitment to team (PCT) scale to segment sport consumers based on loyalty. Sport Marketing Quarterly, 9, 15-25.

Martilla, J., \& James, J. (1977). Importance-Performance Analysis. Journal of Marketing, 14, 77-79. doi:10.2307/1250495

Miller, P., \& Kerr, G. (2002). The athletic, academic, and social experiences of intercollegiate student athletes. Journal of Sport Behavior, 25, 346-367.

Miranda, F.J., Chamorro, A., Murillo, L.R., \& Vega, J. (2010). An importance-performance analysis of primary health care services: Managers vs. patients perceptions. Journal of Service Science and Management, 3, 227-234. doi:10.4236/jssm.2010.32028

NAIA. (2012). List of member conferences. Retrieved September 1, 2012. http://www.naia. org/ViewArticle.dbml?DB_OEM_ID=27900\&ATCLID=205322955

OCAA. (2011). History of the OCAA. Retrieved August 4, 2011 from http://ocaa.com/ about/history.

OUA. (2001). Student-athlete recruitment pressures in Ontario. Unpublished Report. Hamilton: Ontario University Athletics.

OUA. (2012). OUA directory. Retrieved August 4, 2011 from http://oua.ca/directory/oua.

Parent, M., \& Seguin, B. (2008). Toward a model of brand creation for large-scale events: The impact of leadership, context, and nature of the event. Journal of Sport Management, 22, 526-549.

Rial, A., Rial, J., Varela, J., \& Real, E. (2008). An application of importance-performance analysis (IPA) to the management of sport centres. Managing Leisure, 13, 179-188. doi:10.1080/13606710802200878

Robinson, M., \& Miller, J. (2003). Assessing the impact of Bobby Knight on the brand equity of the Texas Tech basketball program. Sport Marketing Quarterly, 12(1), $56-59$.

Ross, S. (2006). A conceptual framework for understanding spectator-based brand equity. Journal of Sport Management, 20, 22-38.

Ross, S.D., Bang, H., \& Lee, S. (2007). Assessing brand associations for intercollegiate hockey. Sport Marketing Quarterly, 16, 106-114. 
Ryan, C.J., Groves, D., \& Schenider, R. (2007). A study of factors that influence high school athletes to choose a College or University, and a model for the development of player decisions. College Student Journal, 41(3), 532-539.

Sevier, R.A. (2000). Building an effective recruiting funnel. Journal of College Admission, $169,10-19$.

Skok, W., Kophamel, A., \& Richardson, I. (2001). Diagnosing information systems success: Importance-performance maps in the health club industry. Information \& Management, 38, 409-419. doi:10.1016/S0378-7206(00)00076-8

Slack, N. (1994). The importance-performance matrix as a determinant of improvement priority. International Journal of Operations \& Production Management, 14(5), 59-75. doi:10.1108/01443579410056803

Tarrant, M.A., \& Smith, E.K. (2002). The use of a modified importance-performance framework to examine visitor satisfaction with attributes of outdoor recreation settings. Managing Leisure, 7, 69-82. doi:10.1080/13606710210137246

Temporal, P. (2002). Advanced brand management. New York: John Wiley \& Sons.

Venkat, R. (2005). Building brands one customer at a time. The Workplace Review, October, 38-55.

Wakefield, K.L., \& Sloan, H.J. (1995). The effects of team loyalty \& selected stadium factors on spectators' attendance. Journal of Sport Management, 9, 153-172.

Wakefield, K.L., Blodgett, J.G., \& Sloan, H.J. (1996). Measurement and management of Sportscape. Journal of Sport Management, 10, 15-31.

Wohlgemuth, D., Whalen, D., Sullivan, J., Nading, C., Shelley, M., \& Wang, Y. (2007). Financial, academic, and environmental influences on the retention and graduation of students. Journal of College Student Retention: Research. Theory into Practice, 8(4), 457-475. 